\title{
When Double Intention Ignored: A Study of Corruption Judicial Decisions
}

\author{
Muhammad Arif Setiawan dan Mahrus Ali \\ Fakultas Hukum Universitas Islam Indonesia Yogyakarta Indonesia \\ Jln. Tamansiswa No. 158 Yogyakarta Indonesia \\ arif.setiawan@uii.ac.id; mahrus_ali@uii.ac.id
}

Received: 8 Juni 2021; Accepted: 10 Agustus 2021; Published: 25 Agustus 2021

DOI: 10.20885/iustum.vol28.iss3.art1

\begin{abstract}
This study aims to analyze the application of participating perpetrator in court decisions in corruption cases. The research question is whether the double intention as a condition for participating perpetrator in the decision of a corruption case is fulfilled? As a normative legal research, the study in this research is focused on the ratio of four decisions on corruption cases, especially the concept of criminal participation. The results of the study concluded that the double-intentional evidence as a condition for participating perpetrator so was ignored by the panel of judges. The role of involvement of each defendant in the offense of participating perpetrator in the ongoing decision is not described. The judge is not even able to distinguish between the conditions of a person as a perpetrator and the participating perpetrator. In the decisions studied, the judges also mixed the concepts of ordering, advocating, and participating in committing criminal acts of corruption. The judge's inaccuracy in the use of double intention resulted in the emergence of an unfair sentence. Therefore, this study suggests that the Supreme Court should make guidelines for the application of participating perpetrator in corruption cases.
\end{abstract}

Key Words:Corruption case; double intention; participation to crime; ratio dedicendi

\section{Abstrak}

Penelitian ini bertujuan untuk menganalisis penerapan turut serta dalam putusan pengadilan perkara tindak pidana korupsi. Pertanyaan penelitian adalah apakah kesengajaan ganda sebagai syarat turut serta melakukan dipenuhi putusan perkara tindak pidana korupsi? Sebagai penelitian hukum normatif, kajian dalam penelitian difokuskan kepada ratio dedicendi empat putusan perkara korupsi terutama konsep turut serta. Hasil penelitian menyimpulkan bahwa pembuktian kesengajaan ganda sebagai syarat turut serta melakukan diabaikan oleh majelis hakim. Peran keterlibatan tiap-tiap terdakwa pada delik turut serta pada putusan yang dikaji tidak tergambarkan. Hakim bahkan tidak mampu membedakan antara syarat seseorang sebagai pelaku dengan pelaku turut serta. Dalam putusan yang dikaji, hakim juga mencampurkan konsep menyuruh, menganjurkan, dan turut serta melakukan tindak pidana korupsi. Ketidaktepatan hakim dalam penggunaan kesengajaan ganda mengakibatkan timbulnya pemidanaan yang tidak adil. Oleh karena itu, penelitian ini menyarakan agar Mahkamah Agung membuat pedoman penerapan turut serta melakukan dalam putusan perkara tindak pidana korupsi.

Kata-kata Kunci: Perkara korupsi; turut serta melakukan delik; kesengajaan ganda; pertimbangan hukum hakim 


\section{Introduction}

Corruption is widely accepted as one of the transnational organized crimes committed with a very complex modus operandi. ${ }^{1}$ Many actors are involved on a massive scale, ${ }^{2}$ and are difficult to detect. ${ }^{3}$ In Indonesia, this can be seen in the BLBI corruption case, ${ }^{4}$ Wisma Atlet case of Hambalang, ${ }^{5}$ bribery of the former Chief of the Constitutional Court, Akil Mochtar, ${ }^{6}$ and mega corruption of E-KTP.7 In these cases, Article 55 paragraph (1) $1^{\text {st }}$ of the Criminal Code is often used in both the prosecutors' charges and the judges' verdicts. Which means, the concept of participation to crime (medeplegen) has become an important indictment for charging the perpetrator.

It is clear that several kinds of offenses in Law Number 31 of 1999 in conjunction with Law Number 20 of 2001 (Anti-Corruption Law) require specific offender. Article 3 can only be done by someone who has public authority, Article 5 paragraph (2), Article 11, and Article 12 point a and b can also only be carried out by civil servants or state officials. Article 6 paragraph (2) and Article 12 point c and $\mathrm{d}$ which can only be perpetrated by a judge or a lawyer. The limitation of the subject of this offense has serious consequences for participation to crime (medeplegen). They are the ones who qualify as perpetrators (pleger). Apart from that, they are only appropriately placed as participant actors because they are not required to have the same eigenshap (subject, characteristics, and quality) as a perpetrator. The provision of participation to crime is precisely aimed at

${ }^{1}$ John D. Becker, "NGO's with an Attitude and Bayonets: A Consideration of Transnational Criminal Organizations", Denver Journal of International Law and Policy, 2003, hlm. 135. David A. Sadoff, "How Law Enforcement Cooperation abroad is Pivotal to Sustainable Development at Home", Boston University International Law Journal, 2017, hlm. 341

2 Heba Shams, "The Fight against Extraterritorial Corruption and the Use of Money Laundering Control", Law and Business Review of the Americas, 2001, hlm. 88-89. Patrick X. Delaney, "Transnational Corruption: Regulation Across Borders", Virginia Journal of International Law, 2007, hlm. 421

${ }^{3}$ Kevin E. Davis, Guillermo Jorge, Maíra R. Machado, "Transnational Anticorruption Law in Action: Cases from Argentina and Brazil", Law and Social Inquiry, 2015, hlm. 665. Masyhudi, "Membangun Sistem Integritas untuk Pemberantasan Korupsi dalam Sistem Peradilan Pidana”, Jurnal Hukum Ius Quia Iustum, 26, 1, 2019, hlm. 45

${ }^{4}$ J. Danang, Widoyoko, "Reproduksi Korupsi: Studi Kasus Jaksa Urip Tri Gunawan”, Masalah-Masalah Hukum, Vol. 42, No.1, 2013, hlm. 16-17

${ }^{5}$ Mochtar Touwe, Iqbal Sultan dan Hasrullah, "Investigasi Majalah Berita Mingguan Tempo dalam Kasus Korupsi Megaproyek Sarana Olahraga Hambalang”, Jurnal Analisis, Vol. 3, No. 2, 2015, hlm. 90-91.

6 I Wayan Joniarta, "Banalitas Korupsi di Indonesia (Suatu Tinjauan dari Perspektif Budaya)", Jurnal Ilmiah Dinamika Sosial, Vol. 2, No. 1, 2018, hlm. 155

${ }^{7}$ Rina Sovianti, “Analisis Framing: Pemberitaan Penangkapan Kasus Korupsi E-KTP Setya Novanto di Media Daring Detik.Com dan Kompas.Com”, Jurnal Komunikasi, Masyarakat dan Keamanan, Vol. 1, No. 1, 2019, hlm. 49 
expanding the scope of the offense including the subject of the offense so that the involvement of people who do not meet the quality as perpetrators of offenses can still be subject to participation. ${ }^{8}$

The aforementioned perspective is important for the judge when the Public Prosecutor uses together Article 55 paragraph (1) $1^{\text {st }}$ of the Criminal Code with the core offense in the Anti-Corruption Law. Inaccuracies will lead to mistake in formulating participation to crime in the judge's legal considerations (ratio dedicendi). Therefore, it is important to examine the accuracy of the use of double intention as an element of participation to crime in the court decisions of corruption cases. Unfortunately, previous study on this matter only focused on particular case, ${ }^{9}$ the difference application of participation to crime between the private sector and the government official, ${ }^{10}$ the judge legal reasoning in determining the criminal liability of the defendants in one case, ${ }^{11}$ and the limits of the criminal responsibility of participation in criminal matters. ${ }^{12}$

\section{Problem Formulation}

Based on the above research background, the legal problem formulation of this research is, has double intention as an element of participation to crime been fully satisfied in the corruption judicial decisions?

\section{Research Purposes}

The purpose of this study is to analyze whether or not the double intention as the element of participation to crime has fully been satisfied in the corruption judicial decisions.

\footnotetext{
8 Muhammad Ainul Syamsu, Pergeseran Turut Serta Melakukan dalam Ajaran Penyertaan Telaah Kritis Berdasarkan Teori Pemisahan Tindak Pidana dan Pertanggungjawaban Pidana, Prenada Media, Jakarta, 2014, hlm. 72-76

9 Basir Rohromana, "Penerapan Ajaran Turut Serta dalam Tindak Pidana Korupsi", Yuridika, Vol. 32, No. 2, 2017, hlm. 225-226

10 Alifia Swatika Maharani, "Penyertaan dalam Delik Jabatan pada Tindak Pidana Korupsi", Jurist-Diction, Vol. 3, No. 4, 2020, hlm. 1327-1328

${ }_{11}$ Muhammad Musa, "Penalaran Hakim Menerapkan Ajaran Penyertaan dalam Putusan Tindak Pidana Korupsi Pada Bank Riau-Kepri”, Masalah-Masalab Hukum, Vol. 46, No. 4, 2017, hlm. 353-356

12 Franco Marcello Moningka, "Penerapan Ajaran Deelneming dalam Tindak Pidana Korupsi", Lex Crimen, Vol. 7, No. 5, 2018, hlm. 26-31
} 


\section{Research Method}

This research was a doctrinal (normative) legal research because what studied was the legal theory and the ratio dedicendi of court decisions. ${ }^{13}$ The focus of research is on whether or not the concept and elements of participation to crime (medeplegen) are reasonably in the decisions of corruption cases using statutory, conceptual, and case approach. The primary legal sources are in the form of the Anti-Corruption Law, the Criminal Code, and 4 corruption judicial decisions included participation to crime, while the secondary legal sources include books, journals and research about participation to crime and offenses of corruption. The legal sources were then analyzed qualitatively through data reduction, presentation, and drawing conclusions. ${ }^{14}$

\section{Result and Discussion}

\section{Participation to Crime: A Conceptual Approach}

Participation to crime (medeplegen) is defined as to two or more people who consciously commit an offense together. There must be close cooperation among perpetrators when committing an offense (Moeljanto, 1983). ${ }^{15}$ In order for two or more people can be called as a participant actor(s), double intention must be met. Meaning there must be intention to cooperate and the implementation of an offense together is committed intentionally. The first one requires a deliberate cooperation. Here, it must prove that there are two forms of deliberation, namely deliberate cooperation and deliberate action to bring about a result of offense. The second implies that an offender does not require to completely meet all elements of the offense or that the act of carrying out the offense does not necessarily have to realize by the participating perpetrator. In participation to crime, each perpetrator must meet double intention. This is different from a perpetrator who requires meeting all elements of offense. ${ }^{16}$

13 Depri Liber Sonata, "Metode Penelitian Hukum Normatif dan Empiris: Karakteristik Khas dari Metode Penelitian Hukum”, Fiat Justisia Jurnal Ilmu Hukum, Vol. 8, No. 1, 2014, hlm. 25-27

14 Ahmad Rijali, “Analisis Data Kualitatif”, Jurnal Alhadharah, Vol. 17, No. 33, 2018, hlm. 83-84

15 Moeljanto, Hukum Pidana Delik-delik Percobaan Delik-delik Penyertaan, Bina Aksara, Jakarta, 1983, hlm.

16 Remmelink, J, Hukum Pidana: Komentar atas Pasal-pasal Terpenting dalam Kitab Undang-undang Hukum Pidana Belanda dan Padanannya dalam Kitab Undang-undang Hukum Pidana Indonesia, Gramedia Pustaka, Jakarta, 2003, 
Participation to crime has three important characteristics. First, the execution of an offense involves two or more people. Second, all those involved actually collaborated physically in the committing the offense. Third, the occurrence of physical cooperation is not due to coincidence, but has indeed been an agreement that has jointly planned before. ${ }^{17}$

The purpose of participation to crime is not realizing an offense, but rather carrying out a behavior that causes an offense. ${ }^{18}$ Subsequently, there is no obligation for each party involved to fulfill all the elements of the offense. Therefore, there are possibilities of that involvement. The actions of each party involved in an offense individually have essentially fulfilled all the elements of the offense. The actions of each party involved in an offense do not fulfill all the elements of the offense, but if all the actions of each of the parties involved combined, then all the elements in the offense formulation fulfilled. Finally, between two or more people who are involved in physical cooperation at the time of committing an offense, there is actually only one person whose actions actually fulfill all the elements of the offense, but other has important roles in completing the occurrence of the offense. ${ }^{19}$

\section{Participation to Crime in Corruption Court Decisions The Case of Ridwan Mukti ${ }^{20}$}

In this case, defendant I Ridwan Mukti, the former Governor of Bengkulu Province together with defendant II Lily Martiani Maddari, and Rico Diansari were charged with accepting bribery from Jhony Wijaya, one of the contractors who won the goods procurement project and/or services in Bengkulu Province. On June 20, 2017 around 08.00, Jhoni Wijaya arrived at the Rico Putra Selatan Ltd office. After meeting with Rico Diansari, Jhoni Wijaya handed over the money amounting to IDR1,000,000,000.00 and was witnessed by Haris Taufan Tura. Haris

\footnotetext{
hllm. 314-315. Firmansyah Hilipito, F, "Pertanggungjawaban Pidana terhadap Turut Serta (Medeplegen) Melakukan Tindak Pidana Menurut KUHP”, Lex Privatum, Vol. 4, No. 5, 2016, hlm. 132

${ }_{17}$ Agusman Heri, "Analisis Yuridis terhadap Tindak Pidana Penyertaan Pembunuhan (Studi Putusan MA Nomor 2462/Pid.B/2017/PN Medan”, Jurnal Hukum Responsif, Vol. 11, No. 2, 2018, hlm. 131-132.

${ }_{18}$ Roeslan Saleh, Tentang Delik Penyertaan, Universitas Islam Riau, Pekanbaru, 1989, hlm. 32

${ }^{19}$ Latifa Aulianisya, "Tinjauan Terhadap Ajaran Turut Serta dalam Tindak Pidana Pembunuhan pada Perkara nomor:85/PID/B/2012/PN.BRB”, Al-Qisthu, Vol. 15, No. 2, 2018, hlm. 11

${ }^{20}$ Bengkulu Court Decision, Decision No. 45/Pid.Sus/TPK/2017/PN.BGL
} 
Taufan Tura then made receipts as if they were for material payments. On the same day, Rico Diansari went to Lily Martiani Maddari's house by confirming beforehand to Rian Hidayat (Bengkulu Governor Adjutant) to confirm the presence of Lily Martiani Maddari in her house.

At around 09.00, Rian Hidayat directed Rico Diansari to wait in the guest room. Lily Martiani Maddari then met with Rico Diansari without Ridwan Mukti's presence because Ridwan Mukti had already left for the Governor's Office to carry out his duties (chairing the meeting). Furthermore, Rico Diansari handed over the black cardboard to Lily Martiani Maddari. A few moments later, KPK catch red-handed Rico Diansari and Lily Martiani Maddari along with money amounting to Rp. 1,000,000,000.00 which found in a safe box belonging to Lily Martiani Maddari.

The panel of judges stated that both defendant I and defendant II were proven guilty to have accepted the bribes jointly from Jhonny Wijaya and violated Article 12 point a of Anti-Corruption Law jo Article 55 paragraph (1) $1^{\text {st }}$ of the Criminal Code. The defendants have proven to participate in the offense due to the agreement between the perpetrators and the close cooperation between witness Rico Diansari, defendant II and defendant I, which manifested in the roles of each perpetrator so that a criminal act accomplished and the resulting consequences are as follows: ${ }^{21}$

a. The request of defendant I to Kuntadi to coordinate with Rico Maddari for the project auction at the PUPR Office of Bengkulu Province;

b. Defendant I has ordered Kuntadi to summon the winning partners to meet him in Jakarta. After this meeting, defendant II had a meeting with Rico Diansari and Rico Maddari. During the meeting, defendant II asked Rico Diansari to provide a fee for PUPR projects in Bengkulu Province from the winning bidder of $10 \%$ of the contract value;

c. On June 5, 2017, defendant I was disappointed and angry because he did not know the winners of the auction, including Jhoni Wijaya, and was not the success team in the local election, as well as could cancel the auction he had won and blacklist;

d. Rico Diansari stated that there was a request for a fee from defendant I through defendant II amounting to $10 \%$ of the contract;

e. On June 20, 2017, Rico Diansari received a gift from Jhoni Wijaya for IDR $1,000,000,000$. The money has been given by Rico Diansari to defendant II.

${ }^{21}$ Bengkulu Court Decision, Decision No. 45/Pid.Sus/TPK/2017/PN.BGL, p. 220-230 
According to this study, the legal facts above are not sufficient enough that defendant I as the person who was guilty participated together with II and Rico Diansari committing the offense in Article 12 (a) of the law with several arguments. First, there are no legal facts show that there was an intention to cooperate and deliberately to bring up a consequence of the offense between defendant I and defendant II or between defendant I and Rico Diansari. What was actually revealed is that there was an intention to cooperate and a deliberation to bring up a result of the offense between Defendant II and Rico Diansari. This is supported by two legal facts, namely the meeting in April or May 2016 in Kemang Village, Jakarta and the meeting on 2 June 2017 at around 20.00 at the Coffee Club Senayan City, Jakarta between Defendant II and Rico Diansari. During these meetings, defendant II asked Rico Diansari to provide a fee for PUPR projects in Bengkulu Province from the auction winner amounting to $10 \%$ of the contract value. ${ }^{22}$ These two legal facts are strengthened by Jhoni Wijaya's statement that the emergence of the $10 \%$ figure comes from Rico Diansari. ${ }^{23}$

The realization of cooperation is manifested by both defendant II and Rico Diansari in the form of the execution of the joint offense. On June 20, 2017, at around 08.00 at the office of Rico Putra Selatan Ltd Bakti Husada Street No. 71-A Lingkar Barat, Gading Cempaka District, Bengkulu City, Rico Diansari received a gift of IDR 1000,000,000 from the Jhoni Wijaya. At 09.10 on the same day, Rico handed over the money to defendant II. This money actually related to project fees at the PUPR Office of Bengkulu Province. Although the criteria for participation has met, both defendant II and Rico Diansari cannot be charged and convicted under Article 12 (a) of the Law because both were not civil servants. ${ }^{24}$

Second, regarding the implementation of a joint offense, the abovementioned legal facts are still far from the occurrence of an offense in Article 12 (a). There was no legal implication whatsoever from the actions of defendant I on the two points above because they were neutral acts. Therefore, both objective

\footnotetext{
22 Bengkulu Court Decision, Decision No. 45/Pid.Sus/TPK/2017/PN.BGL, p. 110 \& 220

${ }^{23}$ Bengkulu Court Decision, Decision No. 45/Pid.Sus/TPK/2017/PN.BGL, p. 83

24 Vidya Prahassacitta, "Tinjauan atas Kebijakan Hukum Pidana terhadap Penyuapan di Sektor Privat dalam Hukum Nasional Indonesia:Suatu Perbandingan dengan Singapura, Malaysia Dan Korea Selatan”, Jurnal Hukum \& Pembangunan, Vol. 47, No. 4, 2017, hlm. 403
} 
and subjective elements of an offense were very far to the criminal act. Thus, the legal facts were not sufficient to entice defendant I to participate to crime. ${ }^{25}$ Third, defendant I did not have the authority to cancel the auction winner for the project at the PUPR Office of Bengkulu Province. The defendant I cannot intervene to win certain projects. ${ }^{26}$ Based on Presidential Regulation No. 4 of 2015 on the Fourth Amendment to Presidential Regulation No. 54 of 2010 on Government Procurement of Goods and/or Services, the Governor does not have the authority to select and determine the winner of the procurement of goods and/or services. Apart from that, the panel of the judges cannot interpret the disappointment and anger of defendant I as asking for money. ${ }^{27}$

Fourth, the request for a fee of $10 \%$ of the contract value for projects at the PUPR Office of Bengkulu Province only came from Rico Diansari's testimony. Witness testimony of Rahmani Saifullah, Ahmad Irfansyah, Kuntadi, Jhoni Wijaya, and Sudoto revealed that defendant I did not ask for a commitment fee at all. ${ }^{28}$ The money was actually at the request of defendant II. Only Rico Diansari testified that defendant I asked for a commitment fee of $10 \%$ of the contract value and this statement only heard directly from the testimony of defendant II. Legally, Rico Diansari's testimony must be disregard because he does not meet the qualifications as witness testimony referred in Article 1 point 26 of the Criminal Procedure Code. The testimony of Rico Diansari referred to as the testimonium de auditu that did not have legal binding force as evidence. ${ }^{29}$

The panel of judges, after presenting legal facts which strengthened their argument that Jhoni Wijaya, defendant I, defendant II, and Rico Diansari, were proven to have participated in the act (medeplegen) violation of Article 12 (a) of the Law, then concludes as follows:

Considering, whereas from the description of the legal facts above, it has proven guilty that the roles of defendant I and defendant II respectively as the

${ }^{25}$ Muhammad Ainul Syamsu, Pergeseran Turut Serta Melakukan, Prenada Media, Jakarta, 2014, hlm. 72-76

${ }^{26}$ Bengkulu Court Decision, Decision No. 45/Pid.Sus/TPK/2017/PN.BGL, p. 51, 57, 63, 69 \& 101

${ }^{27}$ Bengkulu Court Decision, Decision No. 45/Pid.Sus/TPK/2017/PN.BGL, p. 84

28 Bengkulu Court Decision, Decision No. 45/Pid.Sus/TPK/2017/PN.BGL, p 49, 53, 65, 81, \& 101

${ }^{29}$ Nedi Gunawan Situmorang, "Kedudukan Hukum (Legal Standing) Keterangan Saksi Testimonium De Auditu sebagai Alat Bukti yang Sah Pra dan Pasca Putusan Mahkamah Konstitusi Nomor: 65/Puu-VIII/2010”, Pakuan Law Review, Vol. 6 No. 2, 2020, hlm. 120. 
person who committed the act (pleger) while Rico Diansari as the person who participated in the act (medepleger). ${ }^{30}$

According to this study, the judges' legal considerations are not accurate. The position of defendant II as the perpetrator (pleger) implies the obligation to fulfill all elements of the offense. ${ }^{31}$ In fact, an offense in Art. 12 (a) of the Law could only be committed by civil servants, whereas the status of defendant II in this case as a housewife. A non-civil servant can only charge under Article 12 (a) if his position as a participant actor (medepleger) which does not require to having the same eigenshap (nature, quality) as the perpetrator.

The supreme court panels consider that both defendants have proven to participate to crime as follow:

In accordance with the application of the provisions of Article 12 (a), the act of accepting a gift or a promise does not require that the recipient of the gift receive the gift or money himself but can do it by someone else who has collaborated with or has a special relationship with the recipient. In this case, defendant I and defendant II were husband and wife. ${ }^{32}$

It is important to note that as long as there is a special relationship with the recipient of the gift (bribe), the bribery is deemed to have occurred and carried out jointly. A Governor's wife who receives a gift or promise from a contractor due to her husband's position is still deemed to have received a bribe with her husband who is a Governor without the need to prove that there is cooperation and implementation of an offense collectively as a condition for participation. ${ }^{33}$ According to this study, the judges' legal considerations were inaccurate, tended to be misleading and dangerous because they undermine the concept and criteria of participation to crime.

\section{The Case of Nur Alam}

In this case, the defendant, former Governor of Southeast Sulawesi Province, charged together with Burhanuddin for committing corruption to the state's

\footnotetext{
${ }^{30}$ Bengkulu Court Decision, Decision No. 45/Pid.Sus/TPK/2017/PN.BGL, p 223

${ }^{31}$ Irena Ulfa, "Pembuktian Penganjur Dalam Tindak Pidana Pembunuhan Anak", Media Iuris, Vol. 1, No. 2, 2018, hlm. 303.

32 Supreme Court Decision, Decision No.1219 K/Pid.Sus/2018, p. 45

33 Linda Ulfa, Mohd Din, dan Dahlan, "Penerapan Ajaran Turut Serta Kasus Korupsi dikaitkan Teori Pertanggungjawaban Pidana”, Kanun Jurnal Ilmu Hukum, Vol. 19 No. 2, 2017, hlm. 290
} 
finance in connection with the permit issuance as outlined in the Decree of the Governor of Southeast Sulawesi No. 828 of 2008 on the Approval of Reserves for Mining Areas to AHB Ltd. The defendant subsequently granted two types of permit; Decree of the Governor of Southeast Sulawesi No. 815 of 2009 on the Approval of Exploration Mining Permit to AHB Ltd and Decree of the Governor of Southeast Sulawesi No. 435 of 2010 on the Approval for the Improvement of Exploration Mining Business Permit to Production Operations Mining Permit to AHB Ltd.

The defendant enriched himself, another person, or a corporation resulting a loss of IDR 4.3 trillion in state finance. This loss said to be due to damage to land and environment in Buton and Bombana regencies of IDR2.7 trillion enriching Billy Indonesia Ltd amounting to IDR1.59 trillion, and defendant by IDR2.7 billions. In addition, the defendant was also proven guilty for receiving gratuity of US \$ 4.49 million from Chen Linze, on behalf of Richcorp International Ltd (RCI) as an investment in AXA Mandiri. Defendant then used it to make an insurance policy with a periodic premium of IDR20 billion per year where the first premium payment used money originating from Richcorp International Ltd. for US \$ 2.49. The panel judges of District Court of Central Jakarta has sentenced defendant for twelve years in prison, then aggravated by the higher court as fifteen years of imprisonment. Supreme Court sentenced the defendant for twelve years in prison and fine for IDR750.000.000 for receiving gratification as promulgated in Art. 12B and 12C of Anti-Corruption Law.

In relation to participation to crime, the court has proven guilty of the defendant based on the several legal considerations. The defendant had directed Ikhsan Rifani who wanted to participate in the mining business, and the defendant directed him to Burhanuddin and Widdi Aswindi. Burhanuddin ordered Kamrullah to prepare a Mining Authority Request Letter from AHB Ltd to the defendant. Upon the request, a Decree on the Approval of the Reservation of Mining Area of AHB Ltd No. 828 of 2008 has been signed by the defendant on December 31, 2008 which is a backdate with the aim of avoiding Law no. 4 of 2009 
which came into force from 12 January 2009. To complete the decision, Burhanuddin signed a staff review dated December 28, 2008. 34

The defendant subsequently signed Decree No. 815 of 2009 dated 17 December 2009 on the Approval of Exploration Mining Permit to AHB Ltd. Request application has submitted by AHB Ltd without being equipped with a serious guarantee deposit and recommendation from the Buton and the Bombana Regent. ${ }^{35}$ The deviation has clearly occurred in the implementation of the issuance of Decree Number 828 of 2008 dated December 31, 2008, Decree of Southeast Sulawesi Province Number 815 of 2009 dated 17 December 2009, Decree No. 435/2010 dated 26 July 2010, and the Decree of the Governor of Southeast Sulawesi Province Number 600 of 2010 dated 20 September 2010. Hence, the defendant committed criminal act jointly as referred to in Article 55 paragraph (1) $1^{\text {st }}$ of the Criminal Code. ${ }^{36}$

According to this study, the panel of judges did not explain which of the defendant and Burhanuddin were the perpetrators of the offense (pleger) and the perpetrators participated (medepleger). Based on Law No. 4 of 2009 on Mineral and Coal Mining, the Governor, Regent or Mayor has the authority to issue mining permit. Therefore, the position of the defendant in the offense to participate in $a$ quo case was as the perpetrator of the offense, while Burhanuddin as the perpetrator participated because he did not have the authority to issue the permit. Unfortunately, elaboration of this position was missing.

The participation to crime also needs to be linked and depends on the evidence of the principal offender. In this case, defendant's actions has not proven guilty to have been abusing the authority that caused losses to the State's finances in Article 3 of the Anti-Corruption Law. In proving the element of 'abusing authority, opportunity or means', the panel of judges stated that the defendant used the power as Governor of Southeast Sulawesi in issuing four Decrees for other purposes wrongly than should be granted. ${ }^{37}$ For this reason, the defendant

\footnotetext{
${ }^{34}$ Central Jakarta Court Decision, Decision No. 123/Pid.Sus/TPK/2017/PN.JKT.PST, p. 773

${ }^{35}$ Central Jakarta Court Decision, Decision No. 123/Pid.Sus/TPK/2017/PN.JKT.PST, p. 774

${ }^{36}$ Central Jakarta Court Decision, Decision No. 123/Pid.Sus/TPK/2017/PN.JKT.PST, p. 775

${ }^{37}$ Central Jakarta Court Decision, Decision No. 123/Pid.Sus/TPK/2017/PN.JKT.PST, p. 751
} 
must charge with Article 165 of the Mining Law. ${ }^{38}$ Moreover, the legal facts in the trial showed that the panel judges of supreme court rejected the amount of IDR1.596.385.454.137 as state financial loss, but merely as the profit of Billy Indonesia Ltd from mining activities. ${ }^{39}$

\section{The Case of Lucas}

The defendant, Lucas together with Dina Soraya were accused of having committed or participated in, deliberately preventing, obstructing, or thwarting directly or indirectly the investigation of the suspect or witnesses in a corruption case. The defendant advised Eddy Sindoro, a suspect in a criminal act of corruption, not to return to Indonesia and strived for him to leave Indonesian territory without immigration checks to avoid interrogation or other legal actions against Eddy Sindoro by the Corruption Eradication Commission (KPK).

On December 4, 2016, Eddy Sindoro wanted to return to Indonesia to face the legal process at the KPK, but advised by the defendant otherwise. The defendant also advised Eddy Sindoro to give up the status of an Indonesian citizen, later assisted by Chua Chwee Chye to make a fake Dominican Republic passport in the name of Eddy Handoyo Sindoro. On August 7, 2018, Eddy Sindoro left for Bangkok from Malaysia, but was then arrested by Malaysian immigration officers for using a fake passport. On August 16, 2018, Eddy Sindoro was proven guilty and expelled from Malaysia to Indonesia considering the status of his offical citizen.

Knowing Eddy Sindoro's plan to be sent home, the defendant asked Dina Soraya's assistance to prepare the Jakarta-Bangkok ticket and coordinated with Soekarno Hatta International Airport officers. Hence when Eddy Sindoro, Chua Chwee Chye, and Michael Sindoro (Eddy Sindoro's son) landed at the airport, they could continue flights out of the country directly without the immigration process. Upon this request, Dina Soraya asked Dwi Hendro Wibowo to pick up Eddy Sindoro and his entourage and immediately proceeded to overseas flights without the immigration process. On October 1, 2018, KPK arrested the

\footnotetext{
38 Any person who issues an IUP, IPR, or IUPK that is contrary to this Law and abuses his authority will be sentenced by a maximum of 2 (two) years imprisonment and a maximum fine of IDR200,000,000.00

${ }^{39}$ Supremecourt Decision, Decision No. 2933 K/Pid.Sus/2018, p. 103
} 
defendant, and on October 12, 2018 Eddy Sindoro turned himself into KPK. The defendant was found guilty and violated offense promulgated in Art. 21 of AntiCorruption Law and Article 55 paragraph (1) $1^{\text {st }}$ of Criminal Code in participation to crime.

The panel of judges argued that the defendant ordered Dina Soraya to condition Eddy Sindoro to enter Indonesia and immediately leave the country again without going through immigration checks. The main intention for doing this was to avoid detection from KPK conducting an investigation into the criminal act of corruption committed by Eddy Sindoro. The defendant also ordered Dina Soraya to take money from Stephen Sunarto at the defendant's office, the Lucas and Parners law office at the 55th floor of Sudirman Sahid Center. Dina Soraya through Nur Rohman then took money from Stephen Sunarto, SGD 46,000 and IDR50.000. It appears that the cooperation carried out between the defendant and Dina Soraya conditioned Eddy Sindoro to enter and leave Indonesia without immigration checks so that immigration crossing data did not record. The action of the defendant had disabled the investigator of KPK to monitor the crossing of Eddy Sindoro resulted in the interruption of investigators from carrying out investigations and other legal actions against Eddy Sindoro. ${ }^{40}$

According to panel judges, there had been close and conscious cooperation carried out by the defendant and Dina Soraya. This cooperation shows the unity of the will and the unity of physical actions that complement one another. The unity of the defendant's desire was that Eddy Sindoro immediately after landing at Seokarno Hatta airport could go directly to Bangkok without immigration checks. There was a physical act that the defendant communicated directly with Eddy Sindoro not to return to Indonesia and gave some money and ordered Dina Soraya to make this happen. Therefore, the defendant was included in the qualifications of the intellectual principal or mastermind who had participated in realizing the offense. Meanwhile, Dina Soraya was the person who carried out the

40 South Jakarta District Court Decision, Decision No. 90/Pid.Sus/TPK/2018/PN.JKT.PST, p. 268 
orders/requests of the defendant by coordinating people who had certain positions at Soekarno Hatta Airport. ${ }^{41}$

According to this study, the panel of judges' legal consideration was weak and even mistaken to understand participation to crime in criminal law. First, the panel of judges used the phrase 'the defendant ordered Dina Soraya to condition Eddy Sindoro to enter Indonesia and return immediately without going through an immigration check' and the phrase 'the defendant ordered Dina Soraya to take money from Stephen Sunarto at the defendant's office' in proving that the defendant was found to have participated with Dina Soraya. An ordered act in penal code has the same meaning as cause others to perpetrate. Those who can be criminally responsible for the offense are only the person who orders them, while the person who carries out the order cannot be criminally liabile for the crime since he is only an instrument. The initiative to commit a criminal act is coming from the person who ordered it. In this case, the defendant himself who actively commits an act, while Dina Soraya only commits an act based on an order from the defendant. The judges' conclusion was problematic where it has clearly been proven that Dina Soraya played a passive role in the accomplishment of an offense. In the participation to crime, the participants of the offense jointly commit an offense actively or collectively as a follow-up to an intention to commit a criminal act together.

Second, the judges have confused between take a direct part in the execution of the act/participation to crime (medeplegen), cause others to perpetrate (doenplegen), and even provoke the execution of the act. On the one hand, the panel of judges concluded that 'there had been close and conscious cooperation carried out by the defendant and Dina Soraya', but at the same time stated that 'the defendant was included in the qualifications of an intellectual principal or mastermind. According to author, the judge's legal consideration was wrong and misleading because intellectual principal only included in cause others to perpetrate and provoke others to execute the act. ${ }^{42}$ In participation to crime,

${ }^{41}$ South Jakarta District Court Decision, Decision No. 90/Pid.Sus/TPK/2018/PN.JKT.PST, p. 269

${ }^{42}$ Fahrurrozi dan Syamsul Bahri M Gare, "Sistem Pemidanaan dalam Penyertaan Tindak Pidana Menurut KUHP”, Media Keadilan Jurnal Ilmu Hukum, Vol. 10 No. 1, 2019, hlm. 55-58. 
double intention must be satisfied; intention to commit an act together and the accomplishment of an offense committed intentionally together. ${ }^{43}$

Third, the judges were unable to clearly explain the position of defendant and Dina Soraya, who was the perpetrator of the offense and who was the participant, or both the defendant and Dina Soraya were the perpetrators of the offense because they fulfilled all the elements of offense set up in Article 21 of the Anti-Corruption Law. Last, participation to crime must have double intention. ${ }^{4}$ Therefore, it would be wrong if the panel of judges agreed to the contents of the indictment of the Public Prosecutor who accused the defendant together with Dina Soraya, even though Dina Soraya herself was only a witness until this verdict has become permanent legal decision.

\section{The Case of Andy Rikie Lam}

The defendant as a Director of Alam Bersemi Sentosa Ltd (ABS) together with Perry Widyananda as a Director of Pertamina Exploration and Production Cepu Ltd Alas Dara Kemuning (PEPC ADK) 2013-2015 period from January 2014 to September 2015 were charged with having committed or participated in an illegal act. The defendant in obtaining a contract for the ADK Block Integrated Drilling Project Management (MPPT) activity before the auction preceded by conducting meetings with Perry Widyananda. The defendant also participated in the auction process that was not in accordance with the provisions of the MPPT Block ADK service procurement at PEPC ADK in 2014. The defendant included two assisting corporations to meet the number of tender participants required in the prequalification documents. Besides, the defendant delivered a copy of the Seram Block Integrated Project Management (IPM) contract between ABS and Citic Seram Energy Ltd Number 527 DRL 07 by changing the title of the document from Drilling Mode Equipment Rental to Integrated Project Management for Seram Block. PEPC ADK finally has appointed ABS as the winner/contractor of goods/services provider for the ADK Block drilling project work.

\footnotetext{
${ }^{43}$ Reza Hidayat, "Penyertaan dalam Tindak Pidana Korupsi (Telaah terhadap Kelalaian dalam Penyertaan untuk Melakukan Tindak Pidana Korupsi)”, e-Jurnal Katalogis, Vol. 3, No. 12, 2015, hlm. 10

${ }_{44}$ Agusman Heri, “Analisis Yuridis terhadap Tindak Pidana Penyertaan Pembunuhan”, Jurnal Ilmiah Abdi Ilmu, Vol. 11 No. 2, 2018, hlm. 131-132
} 
In the implementation of the MPPT Block ADK service procurement, ABS has received standby rig fees for 55 days by making evidence as if it is part of the crater handling work so that the standby rig costs can include cost recovery. This violates the Decree of the Minister of BUMN Number Kep: Kep-117 / M-MBU / 2002 dated July 31, 2002 on the Implementation of Good Corporate Governance Practices in State-Owned Enterprises, PTK-007 on Guidelines for Supply Chain Management of Cooperation Contract Contractors. The defendant's actions enriched himself or ABS causing loss of state finances amounting to USD12.441.110 or equivalent to IDR 185.260.570.945, 83 In this case, the defendant also charged with money laundering.

In proving the defendant's involvement as the participant actor, the panel of judges presented several legal facts. Prior to the announcement of the auction, it appeared that the defendant had held meetings with PEPC ADK, including Perry Widyananda. ${ }^{45}$ Prior to the announcement of the auction, Perry Widayananda and R. Sularso, one of the staff of ABS, made a visit to the well site in the ADK Block. 46 In addition, in carrying out the work of the ADK Block MPPT, the defendant entered into sub-contract agreements with several other companies. ${ }^{47}$ The panel of judges then concluded that the defendant's actions/position in the planning and implementation process of the ADK Block MPPT activities at PEPC ADK were as the perpetrator of an act (pleger). ${ }^{48}$

From a legal perspective, especially in the procurement of goods and services, the responsible party for the planning and auction processing of the ADK Block MPPT work is in the hand of PEPC ADK as the owner of the work. Meanwhile, the role of PT ABS is to implement the work. This construction, from criminal law point of view, actually influences the qualifications of the principals (daader) in complicity (deelneming), and therefore determines which prohibited action (strafbaar) is committed by the participants of the crime, which can be seen as legally and convincingly proven. PEPC ADK organized the planning and auction processing of work. Thus, it is not appropriate if the defendant, on behalf of director of ABS,

\footnotetext{
${ }^{45}$ Central Jakarta Court Decision, Decision No. 103/Pid.Sus-TPK/2019/PN.Jkt.Pst, p 489

${ }^{46}$ Central Jakarta Court Decision, Decision No. 103/Pid.Sus-TPK/2019/PN.Jkt.Pst, p 490

${ }^{47}$ Central Jakarta Court Decision, Decision No. 103/Pid.Sus-TPK/2019/PN.Jkt.Pst, p 491-492

48 Central Jakarta Court Decision, Decision No. 103/Pid.Sus-TPK/2019/PN.Jkt.Pst, p 493
} 
positioned as the principal offender in this case, while Perry Wiyananda as an accessory. In its legal consideration, the Panel of Judges by referring to the BPMIGAS Work Procedure Guidelines Number 007 Revision-II / PTK / I / 2011, on the Guidelines for the Management of the Supply Chain for Cooperation Contractors, stated that the contractor must prepare its calculation with professional expertise by referring to fair market prices. Contractor does not authorize to prepare or determine the self-estimation price (HPS/OE).

The core offense of Article 3 of Anti-Corruption Law concerns the abuse of authority, opportunity or means that can be committed by public officials. ${ }^{49}$ These constitute a complete unit owned by public official, because by giving a position to an administrative official, the authority, opportunity or means automatically follows. Granting a position to public official will include authority. Authority, opportunity or means is an accessory of a public position. ${ }^{50}$ In this case, it is not appropriate for the defendant to be proven guilty for misusing the opportunity or means in his position as Director of ABS. First, the director of a private company is not a public official, hence it is impossible to abuse authority. Second, it is not accurate that the defendant found guilty for misusing the opportunity or means since authority, opportunity or means become an integral part of a public official. ${ }^{51}$ Third, based on the concept of abuse of authority and the theory of autonomy from substantive criminal law, the meaning of every person as the norm address of Article 3 of the Corruption Act can only be carried out by public officials. ${ }^{52}$

Based on the description and analysis of the four decisions above, the judges were unable to meet double intention as the core element of participation to crime. In Ridwan Mukti case, the panel of judges even made two mistakes. They were unable to distinguish between offense of bribery promulgated in Article 12a and 12b of AntiCorruption Law. The nature of the first offense is the process of committing an offense' because a civil servant or state administrator receives a gift or promise where

\footnotetext{
${ }^{49}$ Nicken Sarwo Rin, "Penyalahgunaan Kewenangan Administrasi dalam Undang Undang Tindak Pidana Korupsi”, Jurnal Penelitian Hukum De Jure, Vol. 18, No. 2, 2018, hlm. 265-270

50 Nur Basuki Minarno, Penyalahgunaan Wewenang dan Tindak Pidana Korupsi dalam Pengelolaan Kenangan Daerah, Cetk. Kedua, Laksbang Mediatama, Yogyakarta, 2009, hlm 45

${ }^{51}$ Ibid

52 Indriyanto Seno Adji, Korupsi Kebijakan Aparatur Negara dan Hukum Pidana, CV. Diadit Media, Jakarta, 2006, hlm 426-427
} 
the aim is to mobilize to do or not do something in his position, which is contrary to his obligations. If a civil servant or state administrator 'has done something' so that he receives a gift or promise, it then infringes offense in Article 12b. ${ }^{53}$ The act of the defendant did not fulfill the elements of these two offenses. In addition, the two offenses can only be carried out by civil servants or state officials. Other people who are not civil servants or state administrators can only declare as participant actor. Therefore, the status of defendant II as a perpetrator (pleger) in this case is missing since she has been proven guilty as a housewife. The involvement of the defendant I in participation to crime were also not clear.

In Nur Alam case, the defendant's actions were a violation of the Mineral and Coal Law because the state losses were incurred in this case were not state financial losses and had nothing to do with the defendant's actions in issuing mining permits violating the procedures. The judge's legal considerations which stated that the defendant was proven to have committed corruption together was wrong because the offense in Art. 3 of Anti-Corruption Law was not proven. In Lucas case, the panel of judges was unable to clearly distinguish between causing others to perpetrate (doenpleger), taking a direct part in the execution of the act (medepleger), and intentionally provoking other to execute the act (uitlokker). The term intellectual principal is only known in the concept of causing other to perpetrate (doenplegen) and provoking other to execute the act (uitlokker). In participation to crime, double intention becomes essential element. ${ }^{54}$ In Andy Rikie Lam case, the defendant's action was appropriately as a matter of contractual relation between PEPC ADK and ABS rather than corruption case. As a Director of private company, the defendant cannot abuse his authority, opportunity, or means which are included in the domain of administrative law. Hence, the defendant is unable to be a perpetrator of an offense as well as a participant actor. The penal of judges failed to prove the involvement of the defendant in the accomplishment of an offense and double intention.

53 Artidjo Alkostar, Suap dan Memperdagangkan Pengaruh pada Tindak Pidana Korupsi, makalah disampaikan pada Studium Generale, Fakultas Hukum Universitas Islam Indonesia, 2019, hlm. 3

${ }^{54}$ Herman Sitompul, "Penyertaan dalam Tindak Pidana Korupsi”, Jurnal Hukum dan Keadilan, Vol. 6, No. 2, 2019, hlm. 113-115. Endi Nurinda Putra, "Penerapan Ajaran Penyertaan dalam Tindak Pidanakecelakaan Lalu Lintas yang Dilakukan oleh Anak”, Jurnal Idea Hukum, Vol 1, No. 1, 2015, hlm. 22. 
According to this study, none of the defendants should have been sentenced for their actions either the cases were not offenses of corruption or the judge's inability to prove the involvement of the defendants in the double intention. The detail description of the actions of the defendants in the double intention for participation to crime were poorly found. Hence, the inaccuracy of the use of double intention in participation to crime leads to unjust punishment.

To articulate the application of participation to crime, it is important for the panels of the judges to follow the cumulative steps. At first, there must be convincing evidences either through witness testimony, letters or other legal evidence that there has been an intentional act on each of the perpetrators to commit a crime together. The absent of this fact leads to decision that there is no participation to crime in the case being tried. If the facts are found, then the judge must ensure based on convincing evidence that the joint execution of the crime is committed intentionally by the perpetrators. The actions of each perpetrator is too substantial for the occurrence of the offense.

\section{Conclusion}

Participation to crime requires to prove two cumulative conditions, namely the intention to commit a crime collectively and the accomplishment of a crime committed intentionally for each person involved. Of the four corruption cases examined, none of the judge's legal considerations accurately described the legal facts to the two conditions. They failed to distinguish between the elements of a perpetrator and participant actor as well as conditions for causing other to perpetrate, provoking other to execute the act, and participation to crime. This research is limited to the applying the double intention as an important element of participation to crime in corruption cases. Therefore, it is important to conduct further research related to the use of this concept in other criminal cases. In addition, to prevent unjust punishment, this study recommended the Supreme Court to issue guidelines for the application of participation to crime in court decisions. 


\section{References}

\section{Books}

Adji, Indriyanto Seno, Korupsi Kebijakan Aparatur Negara dan Hukum Pidana, CV. Diadit Media, Jakarta, 2006.

J, Remmelink, Hukum Pidana: Komentar atas Pasal-pasal Terpenting dalam Kitab Undang-undang Hukum Pidana Belanda dan Padanannya dalam Kitab Undangundang Hukum Pidana Indonesia, Gramedia Pustaka, Jakarta, 2003.

Minarno, Nur Basuki, Penyalahgunaan Wewenang dan Tindak Pidana Korupsi dalam Pengelolaan Keuangan Daerah, Cetk. Kedua, Laksbang Mediatama, Yogyakarta, 2009.

Moeljanto, Hukum Pidana Delik-delik Percobaan Delik-delik Penyertaan, Bina Aksara, Jakarta, 1983.

Saleh, Roeslan, Tentang Delik Penyertaan, Universitas Islam Riau, Pekanbaru, 1989.

Syamsu, Muhammad Ainul, Pergeseran Turut Serta Melakukan dalam Ajaran Penyertaan Telaah Kritis Berdasarkan Teori Pemisahan Tindak Pidana dan Pertanggungjawaban Pidana, Prenada Media, Jakarta, 2014.

\section{Journals and Article}

Agusman Heri, "Analisis Yuridis terhadap Tindak Pidana Penyertaan Pembunuhan (Studi Putusan MA Nomor 2462/Pid.B/2017/PN Medan", Jurnal Hukum Responsif, Vol. 11, No. 2, 2018.

Ahmad Rijali, "Analisis Data Kualitatif", Jurnal Alhadharah, Vol. 17, No. 33, 2018.

Alifia Swatika Maharani, "Penyertaan dalam Delik Jabatan pada Tindak Pidana Korupsi", Jurist-Diction, Vol. 3, No. 4, 2020.

Artidjo Alkostar, Suap dan Memperdagangkan Pengaruh pada Tindak Pidana Korupsi, makalah disampaikan pada Studium Generale, Fakultas Hukum Universitas Islam Indonesia, 2019.

Basir Rohromana, "Penerapan Ajaran Turut Serta dalam Tindak Pidana Korupsi", Yuridika, Vol. 32, No. 2, 2017

David A Sadoff, "How Law Enforcement Cooperation abroad is Pivotal to Sustainable Development at Home", Boston University International Law Journal, 2017.

Depri Liber Sonata, "Metode Penelitian Hukum Normatif dan Empiris: Karakteristik Khas dari Metode Penelitian Hukum", Fiat Justisia Jurnal Ilmu Hukum, Vol. 8, No. 1, 2014.

Endi Nurinda Putra, "Penerapan Ajaran Penyertaan dalam Tindak Pidanakecelakaan Lalu Lintas yang Dilakukan oleh Anak", Jurnal Idea Hukum, Vol 1, No. 1, 2015. 
Fahrurrozi dan Gare, Syamsul Bahri M, "Sistem Pemidanaan dalam Penyertaan Tindak Pidana Menurut KUHP", Media Keadilan Jurnal Ilmu Hukum, Vol. 10 No. 1, 2019.

Firmansyah Hilipito, "Pertanggungjawaban Pidana terhadap Turut Serta (Medeplegen) Melakukan Tindak Pidana Menurut KUHP", Lex Privatum, Vol. 4, No. 5, 2016.

Franco Marcello Moningka, "Penerapan Ajaran Deelneming dalam Tindak Pidana Korupsi”, Lex Crimen, Vol. 7, No. 5, 2018.

Heba Shams, "The Fight against Extraterritorial Corruption and the Use of Money Laundering Control", Law and Business Review of the Americas, 2001.

Herman Sitompul, "Penyertaan dalam Tindak Pidana Korupsi”, Jurnal Hukum dan Keadilan, Vol. 6, No. 2, 2019.

I Wayan Joniarta, "Banalitas Korupsi di Indonesia (Suatu Tinjauan dari Perspektif Budaya)", Jurnal Ilmiah Dinamika Sosial, Vol. 2, No. 1, 2018.

Irena Ulfa, "Pembuktian Penganjur Dalam Tindak Pidana Pembunuhan Anak", Media Iuris, Vol. 1, No. 2, 2018.

J. Danang Widoyoko, "Reproduksi Korupsi: Studi Kasus Jaksa Urip Tri Gunawan”, Masalah-Masalah Hukum, Vol. 42, No.1, 2013.

John D Becker, "NGO's with an Attitude and Bayonets: A Consideration of Transnational Criminal Organizations", Denver Journal of International Law and Policy, 2003.

Kevin E. Davis, Guillermo Jorge, Maíra R. Machado, “Transnational Anticorruption Law in Action: Cases from Argentina and Brazil", Law and Social Inquiry, 2015.

Latifa Aulianisya, “Tinjauan Terhadap Ajaran Turut Serta dalam Tindak Pidana Pembunuhan pada Perkara nomor:85/PID/B/2012/PN.BRB", Al-Qisthu, Vol. 15, No. 2, 2018.

Linda Ulfa, Mohd Din, dan Dahlan, "Penerapan Ajaran Turut Serta Kasus Korupsi dikaitkan Teori Pertanggungjawaban Pidana", Kanun Jurnal Ilmu Hukum, Vol. 19 No. 2, 2017.

Masyhudi, "Membangun Sistem Integritas untuk Pemberantasan Korupsi dalam Sistem Peradilan Pidana", Jurnal Hukum Ius Quia Iustum, 26, 1, 2019.

Mochtar Touwe, Iqbal Sultan, dan Hasrullah, “Investigasi Majalah Berita Mingguan Tempo dalam Kasus Korupsi Megaproyek Sarana Olahraga Hambalang", Jurnal Analisis, Vol. 3, No. 2, 2015.

Muhammad Musa, "Penalaran Hakim Menerapkan Ajaran Penyertaan dalam Putusan Tindak Pidana Korupsi Pada Bank Riau-Kepri", Masalah-Masalah Hukum, Vol. 46, No. 4, 2017. 
Nedi Gunawan Situmorang, "Kedudukan Hukum (Legal Standing) Keterangan Saksi Testimonium De Auditu sebagai Alat Bukti yang Sah Pra dan Pasca Putusan Mahkamah Konstitusi Nomor: 65/Puu-VIII/2010", Pakuan Law Review, Vol. 6 No. 2, 2020.

Nicken Sarwo Rin, "Penyalahgunaan Kewenangan Administrasi dalam Undang Undang Tindak Pidana Korupsi", Jurnal Penelitian Hukum De Jure, Vol. 18, No. 2, 2018.

Patrick X Delaney, "Transnational Corruption: Regulation Across Borders", Virginia Journal of International Law, 2007.

Reza Hidayat, "Penyertaan dalam Tindak Pidana Korupsi (Telaah terhadap Kelalaian dalam Penyertaan untuk Melakukan Tindak Pidana Korupsi)", e-Jurnal Katalogis, Vol. 3, No. 12, 2015.

Rina Sovianti, "Analisis Framing: Pemberitaan Penangkapan Kasus Korupsi EKTP Setya Novanto di Media Daring Detik.Com dan Kompas.Com", Jurnal Komunikasi, Masyarakat dan Keamanan, Vol. 1, No. 1, 2019

Vidya Prahassacitta, “Tinjauan atas Kebijakan Hukum Pidana terhadap Penyuapan di Sektor Privat dalam Hukum Nasional Indonesia:Suatu Perbandingan dengan Singapura, Malaysia Dan Korea Selatan”, Jurnal Hukum \& Pembangunan, Vol. 47, No. 4, 2017.

\section{Court Decision}

Bengkulu Court Decision, Decision No. 45/Pid.Sus/TPK/2017/PN.BGL

Central Jakarta Court Decision, Decision No. 103/Pid.Sus-TPK/2019/PN.Jkt.Pst.

Central Jakarta Court Decision, Decision No. 123/Pid.Sus/TPK/2017/ PN.JKT.PST.

South Jakarta District Court Decision, Decision No. 90/Pid.Sus/TPK/2018/ PN.JKT.PST.

Supreme Court Decision, Decision No.1219 K/Pid.Sus/2018.

Supremecourt Decision, Decision No. 2933 K/Pid.Sus/2018. 